\title{
The Acquisition of Faculty Member Publications at Their University Libraries
}

\section{Beau David Case}

In this paper I present a case study to test whether two large ARL libraries adequately collect the monographic mublications of their local fuculty members. The university libraries' consistently low acquisition rates of publications of the ir faculty members ower time and across the publishing industry cunnot be attributed. to any single cause. I discuss the many difficulties in acquiring faculty member publications and conclude by suggesting means to improve the acautisition of faculty member publications. Implications and applicability of these two case studies for other academic libraries also are discussed.

A cademic libraries certainly collect campus faculty member publications, yet Afew collection development policies address the issue of these publications. Futas $(1984,8)$ presents the example of San Diego State University Library:

The Library acquires faculty publications according to the collection policies that determine book and periodical selection in general. That is, those works that are appropriate for an academic library are acquired as they are published. The campus publication The Weekly is reviewed by Technical Service staff routinely for faculty publication notices, but bibliographers are encouraged to give early notice of faculty publications in their subject areas. Textbooks published by the faculty must be purchased under the same criteria as textbooks in general.

This example is quite explicit in its description of the scope of collecting faculty member publications as well as in its detail about acquisition procedures; such emphasis, however, is rare. If faculty member publications are mentioned in collection development policies, often acquisition methods or procedures are not presented. The University of Detroit Library policy, for instance, simply states that local faculty authorship is an acceptable criterion for monograph selection (Futas 1984). The library collection development policies of Easteru Illinois University (Futas 1977) and Iowa State University (Futas 1984), on the

Beau David Case (case.42@osu.edu) is Assistant Protessor and Head, Linguistics \& European Languages Collections. The Ohio State University Libraries, Language and Area Studies Department, Columbus.

Manuscript received July 19, 1999: accepted for publication October 5 , 1999. other hand, place the responsibility for acquisition of campus faculty member publications upon the university archives. Some policy statements even dictate highly selective archives of faculty member publications. For example, the College of St. Catherine collects only faculty member theses, and the University of Wisconsin-Stout collects only faculty members' personal papers (Futas 1984). In many more college and university libraries, there are no guidelines at all for collecting faculty member publications. 
I am working under the assumption that faculty member publications should be collected by the authors' own academic libraries. Although the library literature is devoid of any discussion on the topic, there are myriad commonsense reasons for the acquisition of campus faculty member publications, including:

- faculty members publish in disciplines supported by the university and its library, and so the subjects of the publications should be within the scope of the library collection;

- the university has an obligation to maintain a record of the intellectual achievements of its faculty members, and the library is an appropriate location to house their works, given its existing acquisition, cataloging, reference, storage, and retrieval systems;

- faculty members place their publications on course syllabi, so students need access to the works;

- students are interested in reading the publications of their instructors;

- other faculty members are interested in reading the work of their colleagues;

- tenure and promotion, accreditation, or internal review processes require quick and extensive access to faculty member publications;

- scholars and interlibrary loan librarians often look to the institution of a faculty author for access to the latter's scholarship;

- faculty members want their publications collected by the library for personal gratification, or because access to their work leads to further scholarship, citations, intemal promotion, and intemational recognition; and

- it just makes good public-relations sense for a library to collect the publications of its faculty members.

Many prospective faculty members accept or decline job offers based upon the quality of the academic library. For example, Cluff and Murrah (1987) polled faculty members at the four largest public universities in Texas. They found that $49.7 \%$ of faculty members surveyed considered the library a significant factor in accepting their present position, $49.7 \%$ visited the library on their own during on-site interviews, and $68.2 \%$ of the faculty members surveyed considered the importance of library resources in research efforts "considerable" or "very high." Hart (1955) and Hamlin (1981) also provide anecdotal and historical evidence respectively for the value that faculty members place on their libraries in making job decisions. The way in which faculty members typically evaluate libraries is significant in our discussion. The saying goes that academics often evaluate a library by performing two searches in the catalog: first for the essential reference tool or joumal in their field, and then for their own publica- tions. Perhaps this is so because bibliographers already know that faculty members want the library to acquire their publications. Faculty members will alert bibliographers to their new publications, usually after the library has failed to acquire those publications in a timely mamer. My own informal queries to several bibliographers nationally confirm this. One librarian noted that his faculty members put their requests in terms of comparative library evaluation: "Library $\mathrm{X}$ and $\mathrm{Y}$ have my new book, so why doesn't our library have it?"

Authors in the library literature treat faculty member publications only in terms of libraries creating campus faculty member bibliographies (e.g., MacCorkle 1991; Poporic 1985). The reasons for creating the bibliographies vary. Key and Sholtz (1973), Lee, Gratz, and White (1976), McKee and Feng (1979), and Mansheim and Thompson (1994) cite the bibliography's importance to library directors and school deans and faculty members in writing annual reports or newsletters, and for public relations efforts. Key and Potter (1987) also point out that the bibliography is an important record of an institution's scientific achievement. Dess (1997) and Hughes (1995) use bibliographies as a factor in journal cancellation projects. Only Fenichel (1990) and Jenkins (1995) use the bibliography for collection development. Fenichel uses the bibliography as an aid in journal selection. Jenkins promotes the creation of bibliographies as a way for college librarians to better understand the faculty and thus to enhance collection development. None of these authors discusses either the rigor or the success of the results of acquiring faculty members' publications. In this paper I address these issues in the acquisitions of faculty publications by academic libraries.

\section{Method}

For this study, two top-twenty ARL libraries were chosen based on their similarities in size, scope, and geographic proximity. Both libraries, henceforth called Library A and Library B, are members of the Committee on Institutional Cooperation (CIC), which comprises the Big Ten athletic conference plus the University of Chicago. Two libraries were studied for reasons of economy: by means of two case studies, I will be able to provide a preliminary investigation into the collection habits of similar academic libraries, the results of which may be applicable to other ARL libraries, if not academic libraries in general. The two libraries in this study are also similar in their lack of collection development policies or procedures addressing faculty member publications. Each university provided alphabetical lists of faculty members by rank. All faculty members were included in the lists, including the faculty members of professional schools.

Numbers were assigned to authors, and 10\%-samples were randomly generated from each faculty member rank 
list using a simple Unix-based $\mathrm{C}++$ program. The figure of $10 \%$ was chosen, again, for economy: the figure is small enough to make the study a manageable size (hundreds of faculty members and thousands of publications were taken into account), while at the same time being large enough to yield statistically valid results. The OCLC Online Computer Library Center WorldCat was used to compile faculty member bibliographies. Included were monographs (designated by the OCLC MARC fixed field) authored by the faculty members or monographs with the faculty members as an added entry author.

Excluded were all other MARC-delineated formats (joumals, audio-visuals, computer files, and archives). By this definition of monograph, included in this study were books, government documents, pamphlets, and other printed publications. Manually excluded from this category were article offprints, sine nomine items, theses and other unpublished works, and translations of faculty members' own titles into other languages. In cases of titles with same author names but different subject areas, the faculty members were asked to verify that the publications were theirs.

The author bibliographies then were checked against the holdings of the faculty members' own academic libraries, producing a ratio of published materials to actual materials acquired. Both online and card catalogs were consulted, due to incomplete catalog retroconversion. In cases of multiple imprints or editions, the library was considered to hold a title if it had at least one of the variations in their collection. Next, the results for each library's faculty member publications holdings were classified by imprint date and publisher type. Finally, the data were subjected to several statistical analyses

\section{Results}

The breakdown of faculty rank for both libraries is given in table 1. WorldCat searches revealed that a number of faculty members had no titles; these faculty members were dropped from the sample. The final numbers of faculty members examined also are presented in table 1. WorldCat searches for Library A faculty members yielded 40 titles by assistant professors, 90 titles by associate professors, and 691 titles by professors. WorldCat searches for Library B faculty members yielded 63 titles by assistant professors, 246 titles by associate professors, and 626 titles by professors. The proportions of faculty members publications to holdings are presented in tables 2 and 3 .

The statistical analysis of these figures is presented in table 4 . From these analyses, we can conclude with $95 \%$ confidence that the probability of Library A owning a campus faculty members publication is $72.2 \%$, and of Library B is $59.2 \%$.

Table 1. Breakdown of Faculty Rank by Library

Assistant Associate

Professors Professors Professors

Initial Sample

Library A

Library B

48

49

116

97

140

207

Sample with Zero-Publication

\section{Faculty Removed}

Library A

$14 \quad 32$

88

Library B

22

63

128

It is possible that assistant professors, because they are new to campus and thus not well known by bibliographers, have a lesser chance to have their publications acquired by the library. Conversely, professors may have a better chance. Similarly, Library A's faculty members may have a better chance of having their publications acquired than by Library B's faculty members, or vice versa. In order to test whether faculty member rank alone, faculty member affiliation, or faculty member rank plus institutional affiliation influences the rate of acquisition, the data were applied to a fixed effect logistic regression analysis with overdispersion, followed by a Wald Type 3 analysis using the GENMOD procedure in SAS. The results returned values of $P=0.415$ for faculty members rank, $\mathrm{P}=0.061$ for institution, and $\mathrm{P}=0.944$ for the interaction between rank and institution. Figure 1 summarizes the analysis. The confidence intervals at each rank overlap one another, and hence the analysis did not reveal a

Table 2. Library A Acquistion Rate

\begin{tabular}{lrc} 
& \multicolumn{2}{c}{ Acquisition rate } \\
Faculty rank & No. & $\%$ \\
Assistant Professor $(\mathrm{N}=14)$ & $25 / 40$ & 62.5 \\
Associate Professor $(\mathrm{N}=32)$ & $67 / 90$ & 74.4 \\
Professor $(\mathrm{N}=88)$ & $502 / 691$ & 72.6 \\
\hline \multicolumn{1}{c}{ Total $(\mathbf{N}=\mathbf{1 3 4})$} & $\mathbf{5 9 4 / 8 2 1}$ & $\mathbf{7 2 . 2}$
\end{tabular}

Table 3. Library B Acquistion Rate

Faculty rank

Assistant Professor $(\mathrm{N}=22)$

Associate Professor $(\mathrm{N}=63)$

Professor $(\mathrm{N}=128)$

Total $(\mathrm{N}=213)$
Acquisition rate

No. $\quad \%$

$33 / 65 \quad 50.8$

$164 / 255 \quad 64.3$

$639 / 1091 \quad 58.6$ 


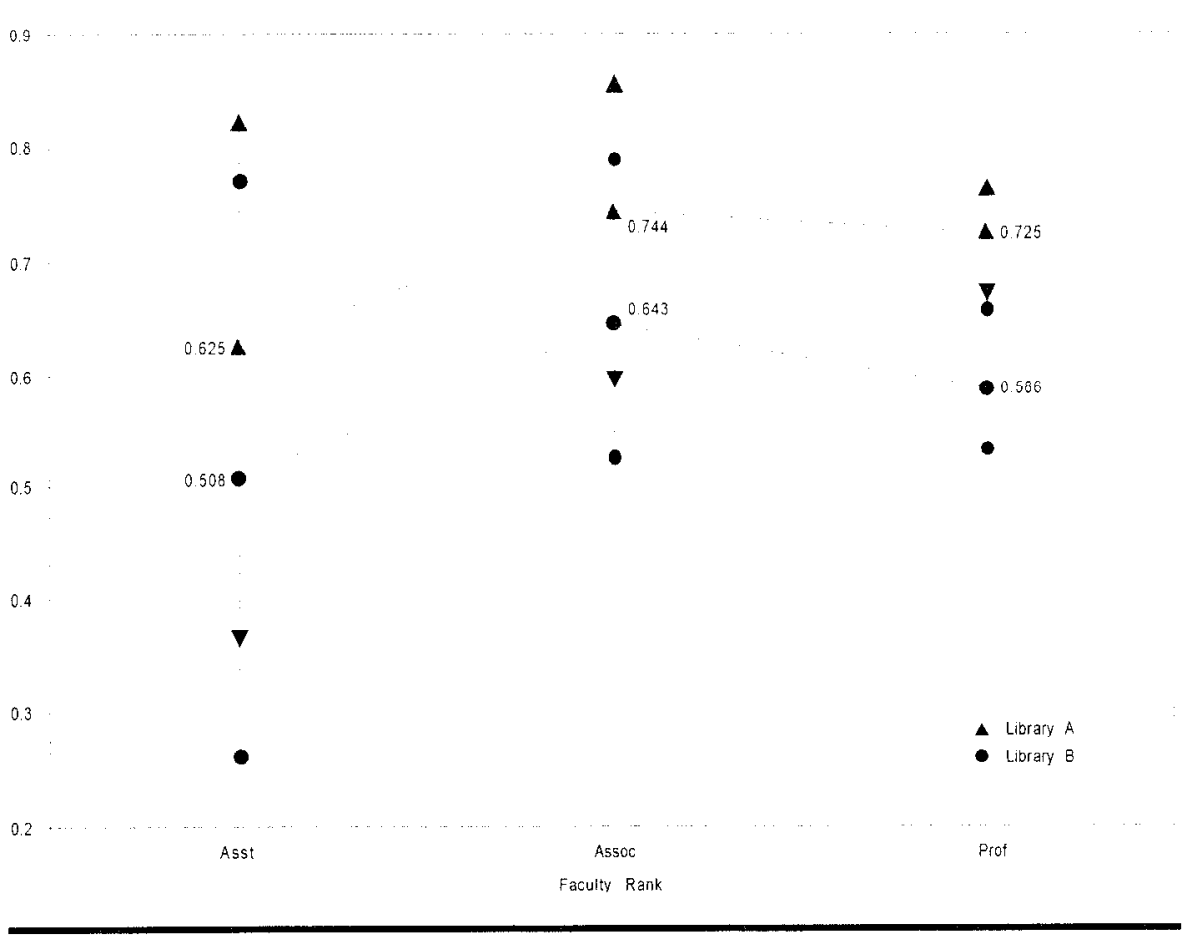

Figure 1. Acquisition Rates and Confidence Intervals

bers' publications. However, the value for institution ( $\mathrm{P}=0.06 \mathrm{l}$ ) suggests a tendency for Library $A$ to be more successful than Library B in acquiring faculty member publications.

\section{Discussion}

The most striking finding is that the overall acquisitions rates are quite low. The results are perhaps more surprising if the data are presented slightly differently. If we take the total number of titles not acquired for each faculty member's rank, and divide by the total number of faculty members in the ranked sample, we can determine the average number of titles the library lacks per faculty member. At Library A, for each assistant professor, the library lacks an average of 1.1 titles; for each associate professor, the library lacks an average of 0.7 titles;

statistically significant difference in the acquisition rates across the three professorial ranks ( $\mathrm{P}=0.415)$. The mean profiles are parallel, reflecting no interaction between rank and institution ( $\mathrm{P}=0.944)$. In other words, the analysis rejects the hypotheses that rank, institutional affiliation, or a combination of the two influenced the acquisition of faculty mem-

Table 4. Bonferroni Simultaneous Multiple Comparisons of Acquisition Rates

\begin{tabular}{lccc}
\hline & $\begin{array}{c}\text { Lower } \\
\text { Bound }\end{array}$ & $\begin{array}{c}\text { Upper } \\
\text { iound }\end{array}$ \\
Overall & & & \\
Library A & 0.680 & 0.722 & 0.763 \\
Library B & 0.544 & 0.592 & 0.640 \\
& & & \\
Library A by Faculty Rank & & & \\
Assistant Professor & 0.364 & 0.625 & 0.829 \\
Associate Professor & 0.569 & 0.744 & 0.865 \\
Professor & 0.666 & 0.725 & 0.777 \\
& & & \\
Library B by Faculty Rank & & & \\
Assistant Professor & 0.253 & 0.508 & 0.758 \\
Associate Professor & 0.501 & 0.643 & 0.764 \\
Professor & 0.518 & 0.586 & 0.651 \\
\hline
\end{tabular}

Note: $95 \%$ confidence level for each professor, an average of 2.1 titles. In other words, if a professor of engineering had published four titles, Library A most likely would have acquired only two of them. These figures seem surprisingly low both to me and to collection development librarians at the two libraries, who were interviewed following this study. Literature bibliographers, for example, noted that they had collected the entire works by both major and minor world writers, and at least $80 \%$ of the intcrnational criticism on those same authors. They thus were surprised that they had only collected approximately two-thirds of their own faculty members' scholarly output.

Several factors might be behind the low acquisitions rates. First, the library may not have had the necessary funds to purchase the publications, although this is unlikely given that these particular libraries have anong the largest acquisitions budgets in the United States. Mobility of scholars might be a factor. For example, many faculty members of all ranks accept new positions, and so it could be that upon arrival at their new institution, the library was unable to acquire the faculty member's earlier, out-of-print publications. However, today the acquisition of out-of-print materials is greatly facilitated by online collective second-hand store catalogs such as Advanced Book Exchange, and by companies such as Acme Bookbinding, which can produce bound, acid-free photoduplicates of out-of-print books.

In other cases, materials of an ephemeral or popular nature might not have been acquired because they were 
inappropriate for the collection. Textbooks, for example, are anathema to many academic libraries (although in this study many more textbooks were acquired than not). In some cases, it may be that the librarians did acquire certain titles, but by the time of this study, the items had been withdrawn from the library catalog due to damage or loss. Tenure of collection development librarians could also be a factor. The more years a bibliographer spends as the liaison to an academic department, the more familiar she becomes with the faculty members, bibliographically and socially, which helps to bring faculty member publications into the library.

Tables 5 through 8 are presented in order to examine more closely the low acquisition rates at Library $\Lambda$ (tables 5 and 6) and Library B (tables 7 and 8) respectively. Tables 5 and 7 present acquisitions by class of publisher. The categories included the following: U.S., U.K., and Canadian university presses; other domestic academic publishers, such as university departments, schools, or independent institutes; domestic commercial presses, including those with foreign and domestic offices (John Benjamins, for example, which produces Amsterdam and Philadelphia imprints); professional associations, think tanks, and museums; U.S., U.N., and N.G.O. government documents; and other foreign presses.

An examination of individual publishers and types of publications for most categories provided inconclusive results as to the reason for acquisition failure. For example, there were no specific publishers accounting for a majority of the unacquired commercial titles. There were nearly as many Macmillan titles acquired as there were unacquired; the same can be said of Heinle \& Heinle (a textbook publisher), the Free Press, and so on. An approval plan with a vendor who includes many domestic commercial houses would help to increase the acquisition rate in this category. Acquisition failure in other categories was more conclusive, however. For example, in table 5 the acquisition rates for academic (50.9\%), association (57.5\%), and government $(70.7 \%)$ publications all are below the overall acquisition rate $(72.2 \%)$ for Library A. Similarly, in table 7 the acquisition rates for academic $(57.5 \%)$, association $(44.7 \%)$, and government $(42.0 \%)$ publications all are below the overall acquisition rate $(59.2 \%)$ for Library $\mathrm{B}$.

Regular library processes like approval plans and standing orders usually do not provide for the acquisition of these publications. Generally these materials are not advertised widely and may not be available commercially. Most of the academic publications not acquired on the part of Library $B$ were working papers of professional schools at major universities. Interestingly, the library had many issues of some working paper series, but lacked a comprehensive collection. A standing order to a few of the series would have increased the acquisition rate in this category. Regarding association publications, many of the failures were published by major national or international societies, such as the Association for Computing Machinery, and some were from more specialized organizations such as the American Entomological Institute. Overall, there were few truly obscure publishers in this category for either library.

Government documents posed a particular problem for both libraries. First, even if a library acquires govemment publications, they may be lost to uscrs, as some libraries do not catalog them (both libraries in this study, however, catalog most govermment documents; and govenument docmment libraries were consulted to determine whether the libraries held the mancataloged materials). Between $33 \%$ and $90 \%$ of government documents may never be obtained due to the immense size of govermments and their lack of adegnate distribution and notification systems for their documents (Bower 1989). Moreover, both libraries in this study are only selective federal depository libraries, acquiring only about one-third of materials. Some of the publications that were not acquired probably would have been obtained had the libraries been full depositories. Yet, many of the govermment publications in question would not have been distributed to depository libraries. For this reason, both libraries in this study camnot hope to rely on their state libraries (each of which is a full federal depository) to acquire campus faculty nember publications. A higher acquisition rate for govermment publications will require an extremely zealous bibliographer.

Foreign publications did not pose a problem, undoubtedly owing to the emphasis of area studies at the libraries and the long presence of area studies librarians at the institutions. Date of publication did pose a problem, however. Table 6 shows the $1940 \mathrm{~s}(16.7 \%), 1960 \mathrm{~s}(53.4 \%)$, and $1970 \mathrm{~s}$ $(69.7 \%)$ all below the overall acquisition rate $(72.4 \%)$ for Library A. Similarly, table 8 shows the 1950 s (39.1\%), 1960s $(63.8 \%)$, and $1970 \mathrm{~s}(54.8 \%)$ all below the overall acquisition rate (59.2\%) for Library B. The low rate in the 1940 s and 1950 s may be explained by loss, as discussed above; however, the sample size is small and thus may not indicate much.

The rates for 1960s and 1970s may be low for several reasons. First, we should note the tremendous increase in scholarly output begiming in the 1950 s as a result of the C.I. Bill, the Cold War, and the National Defense Education Act of 1958. As Osburn (1979) points out, total higher education expenditures accounted for $0.8 \%$ of the Gross National Product in 1950. That share junped to $1.1 \%$ in 1960 and to $2.1 \%$ in 1970 . Higher education saw a similar dramatic increase: 6,633 doctorate degrees were conferred in the United States in 1950; 9,360 in 1960; and 29,872 in 1970. The number of books published in America rose dramatically during the same period. An estimated 124,675 titles were published in the 1950s. That number leapt to 251,584 titles in the 1960s and to 373,658 titles in the 1970s (U.S. Burean of the Census 1951, 1961, 1971; Bowker 1961-80; Publishers Weekly 1952.). The below-average acquisitions rates for the 1960s and 1970s may indicate that the library was unable to 
Table 5. Library A Acquisition Rote by Class of Publisher

\begin{tabular}{|c|c|c|c|c|c|c|c|c|c|c|c|c|c|}
\hline \multicolumn{2}{|c|}{ Iniversity } & \multicolumn{2}{|c|}{ Other } & \multicolumn{2}{|c|}{ Commercial } & \multicolumn{2}{|c|}{ Association } & \multicolumn{2}{|c|}{ Government } & \multicolumn{2}{|c|}{ Foreign } & \multicolumn{2}{|c|}{ Totals } \\
\hline $6 / 6$ & 100 & $2 / 10$ & 20 & $8 / 10$ & 80 & $0 / 2$ & 0 & $6 / 9$ & 67 & $3 / 3$ & 100 & $25 / 46$ & 63 \\
\hline $137 / 151$ & 91 & $69 / 131$ & 53 & $171 / 227$ & 75 & $171 / 227$ & 59 & $21 / 32$ & 66 & $69 / 91$ & 76 & $502 / 691$ & 73 \\
\hline $158 / 173$ & 91 & $81 / 159$ & 51 & $1980 / 262$ & 76 & $42 / 73$ & 58 & $41 / 58$ & 71 & $74 / 96$ & 77 & $594 / 821$ & 72 \\
\hline
\end{tabular}

Table 6. Library A Acquisition Rate by Decade of Publication

\begin{tabular}{|c|c|c|c|c|c|c|c|c|c|c|c|c|c|c|c|c|}
\hline \multirow[b]{2}{*}{ Rank } & \multicolumn{2}{|c|}{$1930 s$} & \multicolumn{2}{|c|}{$1940 \mathrm{~s}$} & \multicolumn{2}{|c|}{$1950 \mathrm{~s}$} & \multicolumn{2}{|c|}{$1960 \mathrm{~s}$} & \multicolumn{2}{|c|}{$1970 \mathrm{~s}$} & \multicolumn{2}{|c|}{$1980 \mathrm{~s}$} & \multicolumn{2}{|c|}{$1990 \mathrm{~s}$} & \multicolumn{2}{|c|}{ Totals } \\
\hline & Xo. & $\%$ & Yo. & $\%$ & No. & $\%$ & No. & $\%$ & Yo. & $\%$ & No. & $\%$ & No. & $\%$ & No. & $\%$ \\
\hline Assistant & $0 / 0$ & $N / A$ & $0 / 0$ & $N / A$ & $0 / 0$ & $N / A$ & $0 / 0$ & $N / A$ & $0 / 0$ & $N / A$ & $12 / 19$ & 63 & $13 / 21$ & 62 & $25 / 40$ & 63 \\
\hline Professor & $2 / 2$ & 100 & $1 / 6$ & 17 & $14 / 18$ & 78 & $54 / 100$ & 54 & $127 / 180$ & 71 & $186 / 228$ & 82 & $118 / 157$ & 75 & $502 / 691$ & 73 \\
\hline Totals & $2 / 2$ & 100 & $1 / 6$ & 17 & $15 / 19$ & 79 & $55 / 103$ & 53 & $138 / 198$ & 70 & $228 / 283$ & 81 & $155 / 210$ & 74 & $594 / 821$ & 72 \\
\hline
\end{tabular}

Table 7. Library B Acquistion Rate by Class of Publisher

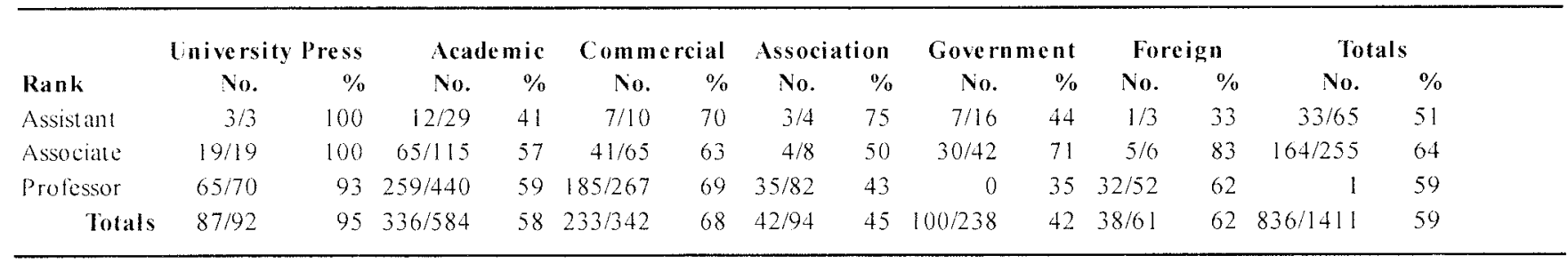

Table 8. Library B Acquisition Rate by Decade of Publication

\begin{tabular}{|c|c|c|c|c|c|c|c|c|c|c|c|c|c|c|c|c|}
\hline \multirow[b]{2}{*}{ Rank } & \multicolumn{2}{|c|}{$1930 \mathrm{~s}$} & \multicolumn{2}{|c|}{$1940 \mathrm{~s}$} & \multicolumn{2}{|c|}{$1950 \mathrm{~s}$} & \multicolumn{2}{|c|}{$1960 \mathrm{~s}$} & \multicolumn{2}{|c|}{$1970 \mathrm{~s}$} & \multicolumn{2}{|c|}{$1980 \mathrm{~s}$} & \multicolumn{2}{|c|}{$1990 \mathrm{~s}$} & \multicolumn{2}{|c|}{ Totals } \\
\hline & No. & $\%$ & No. & $\%$ & No. & $\%$ & No. & $\%$ & No. & $\%$ & No. & $\%$ & No. & $\%$ & No. & $\%$ \\
\hline Assistant & $0 / 0$ & $\mathrm{~N} / \mathrm{A}$ & $0 / 0$ & $\mathrm{~N} / \mathrm{A}$ & $0 / 0$ & $\mathrm{~N} / \mathrm{A}$ & $1 / 4$ & 25 & $6 / 8$ & 75 & $11 / 24$ & 46 & $15 / 29$ & 52 & $33 / 65$ & 51 \\
\hline Professor & $2 / 2$ & 100 & $1 / 3$ & 33 & $9 / 23$ & 39 & $41 / 59$ & 70 & $106 / 198$ & 54 & 1 & 52 & $278 / 415$ & 67 & $639 / 1091$ & 59 \\
\hline Totals & $2 / 2$ & 100 & $1 / 3$ & 33 & $9 / 23$ & 39 & $44 / 69$ & 64 & $137 / 250$ & 55 & $280 / 512$ & 55 & $363 / 552$ & 66 & $836 / 1411$ & 59 \\
\hline
\end{tabular}

adapt quickly enough to the changes in scholarship and in the publishing industry. Another explanation could be that the newly hired bibliographers who replaced faculty members selectors beginning in the 1960s: these new professionals may not yet have known well enongh the faculty nembers or their subject areas.

\section{Conclusion}

Although in this paper I exanined only two large ARL libraries, the results may well be applicable to other aca- demic libraries with similar collection policies and campus faculties, because the basic problem confronting the libraries is the large number of faculty members and their publications. Large academic libraries thus may exhibit acquisition rates results similar to the case studies presented here. Indeed, many academic librarians can replicate results similar to the Pittsburgh Study (Kent 1979) and Trueswell's $80 / 20$ ratio (1969).

Certainly the $95 \%$ pooled confidence intervals for the acquisition rates of Library A $(72.2 \%)$ and Library $B(59.2 \%)$ can be higher. Inprovenend will require excellent communication between faculty members and librariaus and a greater 
reliance upon full-time bibliographers with responsibility and time for pursuit of such publications. Other measures, such as publisher or author-based approval plans, standing orders for university departmental publications, collection development policies and procedures, and assistance from the university administration, all may help to bring in a higher acquisition rate of faculty member publications. All academic librarians desiring to increase the acquisition of faculty member publications could benefit from such measures. Of utmost importance, however, is greater vigilance on the part of bibliographers. For example, bibliographers can ask the departments with whom they have liaison responsibilities to regularly send lists of faculty member publications. Some departments or schools already maintain such lists for faculty members' annual reviews or external accreditation.

It is also likely that departments or schools publish newsletters in which new faculty member publications are listcd. Departmental Web sites may be another source of information. In follow-up interviews with bibliographers, none indicated practicing such methods. In fact, one librarian indicated that such activities were for new bibliographers uncomfortable with their position and unknowledgeable of their faculty members. Furthermore, Library A's reference department received every issue of "Bibliography of Publications by the Faculty Members," published by the university administration between June 1941 and August 1971. This bibliography listed all new faculty member publications, including book chapters, articles, books, reviews, scores, technical reports, and others; however, apparently it was never used as a collection development tool. The pages are not annotated, and a cursory search of citations in the library catalog revealed many titles lacking. Interviews with older and retired bibliographers indicate that the periodical was either unknown altogether or simply not used as a collection development tool. Bibliographers themselves ultimately will increase the acquisition rate of faculty members' publications.

Is it possible for a large university library to acquire $100 \%$ of its faculty member publications? If nothing else, the law of diminishing returns probably will prevent this from happening. Take for example Bastille and Mankin (1980), who determined that $90 \%$ user satisfaction for document retrieval at Massachusetts General Hospital Library would require subscribing to 303 journal titles, but that $100 \%$ satisfaction would require 1,999 titles. Thus, the effort required, both financially and humanly, may prohibit a library from becoming a 100\% library for faculty member publications. Yet, it is possible to acquire more faculty member publications. In many studies in the library literature, researchers discuss the "90\% library" (Abbott 1990; Bourne 1965; Buzzard and New 1983; Carrigan 1988; Gore 1981; Lipetz 1972; Saracevic, Shaw Jr., and Kantor 1977). If the library can supply $90 \%$ of the materials for faculty member research, it seems to follow that that library should be able to, and should strive to, acquire $90 \%$ of the final product of that faculty member research. Indeed, these same faculty member publications are part of the body of knowledge upon which further research will be built and thus should fall within the scope of an academic library's collection. The other reasons for collecting faculty member publications presented in the introduction to this paper also should convince the library to attempt to be a $90 \%$ library for the publications of its own faculty members. Although further study is required to determine whether indeed faculty members place their own publications on syllabi, if those publications circulate, or if the faculty members even care to have their publications acquired, nonetheless the reasons for collecting these materials are compelling.

In this study I only addressed monographic publications, including monographs proper, government documents, society pamphlets, and other printed materials. Not addressed were other formats such as journal articles, andio-visuals, computer files, and archival materials. I do not propose that large academic libraries strive to be $90 \%$ libraries for all faculty member publications (although in a perfect world of unlimited resources and space the notion is attractive). Looking at journal articles alone, this would be impossible-Bastille and Mankin (1980) illustrate the financial folly of such an endeavor, and their results are even more relevant today, two decades and several serials inflation crises later. Rather, I propose that libraries strive to be $90 \%$ libraries in terms of some formats, such as monographs proper, if not monographic publications as defined in this paper (i.e., monographs, pamphlets, government reports, etc.). Academic libraries need not rebuild the Library of Alexandria, nor strive any longer to be just-in-case libraries. Academic libraries strive more and more to serve local needs. Attention to acquiring local faculty member publications certainly supports this goal.

\section{Works Cited}

Abbott, Christine. 1990. What does good look like? The adoption of performance indicators at Aston University Library and Information Services. British Journal of Academic Librarianship 5 : $79-94$

Bastille, Jacqueline, and Carole J. Mankin. 1980. A simple objective method for determining a dynamic journal collection. Bulletin of the Medical Library Association 68: 357-66.

Bourne, Charles P. 1965. Some user requirements stated quantitatively in terms of the $90 \%$ library. In Electronic information handling, ed. Allen Kent and Orrin E. Taulbee, 9.3-110. Washington, D.C.: Spartan.

Bower, Cynthia. 1989. Federal fugitives, DND's and other aberrants: A cosmology. Documents to the People 17: 120-26.

Bouker annual of library and book trade information. 1961-80. New York: R.R. Bowker.

Buzzard, Marion L., and Doris E. New. 1983. An investigation of collection support for doctoral research. College of Research Libraries 44: $469-75$. 
Carrigan, Dennis P. 1985. Librarians and the dismal science. Library Jumal 11:3 (June 15): 22-25.

Cluff, E. Dale, and David J. Murah. 1987. The influence of library resources on faculty recruitment and retention. Jommal of Academic Libnarianship) 1:3 (Ma:): 19-2;3.

Dess, Howard M. 1997. Gauging faculty utilization of seience journads: A defensive strategy for a lean budget era. Science b Technology Libraries 16: 171-90.

Fenichel, Carol II. 1990, Combining reference with collection development: Using Pro-Cite to produce a faculty bibliography and as an ad in joumal selection. Medical Reference Serices Quarterly 9 (Spring): 69-75.

Futas, Elizabeth, ed. 1977. Library acyuisition policies and procedures. Phoenix, Ariz: Oryx.

1984. Library acquisition policies and procedures. $2 \mathrm{~d}$ ed. Phoenix, Ariz.: Oryx.

- 1995. Collection development policies and procedures. $3 \mathrm{~d}$ ed. Phoenix, Ariz: Oryx.

Gore, Daniel, 1981. Curbing the growth of academic libraties. Library Joumal $106(\mathrm{Nov}, 15)$ : 218.3-1.87.

Hamlin, Arthur T. 1981. The umiversity librory in the United States: Its origins and decelopment. Philadelphia: Univ: of Pennsylvaniat.

Hart, James D. 1955. What a scholur expects of acquisitions. In Problems and prospects of the research library, ed. Edwin $\mathrm{E}$. Williams, 57-64. New Brunswick, N.J: Scarecrow Pr.

Hughes, Janet. 1995. Use of faculty publication lists and ISI citation data to identify a core list of joumals with local importance. Librery Acquisitions: Practice \& Theory 19:40,3-13.

Jenkins, Paul O. 1995. Working with faculty to build collections. College \& Research Libraries Neus 56: 322.

Kent, Allen. 1979. Use of library materials: The University of Pittshureh study. New York: Dekker.

Key, Jack D., and Katherine J. Sholtz. 1973. The Mayo Clinic author catalog: A living repository of medical knowledge. Bulletin of the Medical Library Association 61: 228-37.
Lee, Son. Pegrgy Gratz and Joseph White. 1976. Computer-stored faculty publication file using the MT/ST in a mecinm-sized medical center library. Bulletin of the Medical Library Association 64: 25-31.

Lipetz, Ben-Ami. 1972. Catalos use in a latge reseatch library. Librany Quarterly 42: 129-39.

Maccorkle, Lm. 1991. Publishing an annual faculty biblingraphy at the University of Miani. Information Technology and Libraries 10: $121-27$.

Manshein, Renee E., and JoLinda L. Thompson. 1994. Faculty publications databases in acadenic health sciences libraries: A comprehensive survey. Merdical Reference Serices Quarterly 13 (Winter): $21-34$

Mckee, Ama Marie, and Cyril C. H. Feng. 1979. Using comput(rized literature searches to produce faculty publications lists. Bulletin of the Medical Library Association 67 (July): 33-3.35.

Osbum, Charles B. 1979. Acalemic research and library resources: Changing pattems in America. Westport, Comn.: Greenword Pr.

Popovic, Tanya T. 1955. The college faculty bibliography. Catholir. Library World 56: 3.35-39

Potter, Laturie A. 1987. Creating a laculty publications database using Sci-Mate. Medical Reference Sercices Quarterly 6 (Fall): 43 .

Publishers Wekty. 1952. Publishers issued 11,255 titles, including more fiction, in 1951. 161, no. 3 (Jan. 19, 1952): 19.3.

Saracevic, Tefko, William M. Shaw; Jr, and Paul B. Kantor. 1977. Canses and dynamics of user frustration in an academic library. College do Research Libraries 38: 7-18.

Trueswell, Richard wo 1069. Some behavional patterns of library users: The 80/20 nule. Wilson Library Bulletin 43: 458-61.

U.S. Bureau of the Census. 1951. Statistical abstracts of the United States. Washingtom, D.C.: G.P.O.

- 1961. Statistical alostracts of the United States. Washington, D.C.: G.P.O.

- 1971. Statistical alsstracts of the United States. Washington, D.C.: G.P.O. 